\title{
How important are the wetlands in the middle- lower Yangtze River region: An ecosystem service valuation approach
}

Article in Ecosystem Services · December 2014

DOI: 10.1016/j.ecoser.2014.09.004

\section{CITATIONS}

4

6 authors, including:
READS

172
Xiubo Yu

Chinese Academy of Sciences

51 PUBLICATIONS 381 CITATIONS

SEE PROFILE

\section{Yu Liu}

Chinese Academy of Sciences

31 PUBLICATIONS 519 CITATIONS

SEE PROFILE
Luguang Jiang

Chinese Academy of Sciences

33 PUBLICATIONS 325 CITATIONS

SEE PROFILE

\section{Xiyong Hou}

Chinese Academy of Sciences

35 PUBLICATIONS 135 CITATIONS

SEE PROFILE

Some of the authors of this publication are also working on these related projects: 


\title{
How important are the wetlands in the middle-lower Yangtze River region: An ecosystem service valuation approach
}

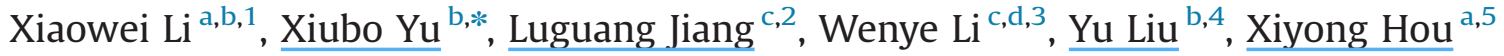 \\ a Yantai Institute of Coastal Zone Research (YIC), Chinese Academy of Sciences (CAS), Yantai 264003, China \\ ${ }^{\mathrm{b}}$ Key Laboratory of Ecosystem Network Observation and Modeling, Institute of Geographic Sciences and Natural Resources Research, \\ Chinese Academy of Sciences, Beijing 100101, China \\ c Department of Natural Resources and Environmental Security, Institute of Geographic Sciences and Natural Resources Research, \\ Chinese Academy of Sciences, Beijing 100101, China \\ ${ }^{\mathrm{d}}$ University of Chinese Academy of Sciences, Beijing 100049, China
}

\section{A R T I C L E I N F O}

\section{Article history:}

Received 30 March 2014

Received in revised form

13 August 2014

Accepted 13 September 2014

Available online 17 October 2014

Keywords:

Wetland ecosystem service

Valuation

Middle-lower Yangtze River region

\begin{abstract}
A B S T R A C T
The middle-lower Yangtze River region, with its lake groups and river systems, is one of the important wetland regions in the world. In this study, physical dimension measurement and monetary evaluation were conducted to estimate the value of wetland services in this region. Results revealed that the total value of the wetland ecosystem services in the middle-lower Yangtze River region is US $\$ 162.5$ billion per year, which reflects the irreplaceable importance of wetlands in this region. The wetland ecosystem service values revealed considerable spatial variability. Poyang Lake, Hong Lake, and Shijiu Lake have the most ecosystem service value. The value of human-made wetlands $\left(2.62 \times 10^{4} \mathrm{US} \$ / \mathrm{ha} / \mathrm{yr}\right)$ is $48 \%$ lower than that of natural wetlands $\left(5.04 \times 10^{4} \mathrm{US} \$ / \mathrm{ha} / \mathrm{yr}\right)$, indicating that the conversion of natural wetlands for aquaculture from the sustainability perspective is not significant. The direct and indirect values of wetland ecosystems are $46.17 \%$ and $53.83 \%$ of the total values, respectively. Recognizing that the value of wetlands in this region is mainly embodied as indirect use values, conservation of the regulating and supporting services should be prioritized in the design of future wetland ecosystem management plans. (c) 2014 Elsevier B.V. All rights reserved.
\end{abstract}

\section{Introduction}

Wetlands provide valuable ecosystem services that contribute to human well-being, including provisioning (e.g., food, fuel wood and water), regulating (e.g., flood control, water quality and water supply), supporting (e.g., biodiversity), and cultural services (e.g., recreation and esthetic) (TEEB, 2010). Historically, wetlands have been viewed as a waste of valuable land that could only be "improved" by drainage and destruction of the wetland (Mitsch and Gosselink, 1986). While wetlands are known to provide valuable ecological services, the understanding on the value of wetland services has generally led to their omission in public decision making, specifically regarding the conservation of wetlands. In this

\footnotetext{
* Corresponding author. Tel./fax: +861064889820.

E-mail addresses: lixw0829@163.com (X. Li), yuxb@igsnrr.ac.cn (X. Yu), jianglg@igsnrr.ac.cn (L. Jiang), liwy.12s@igsnrr.ac.cn (W. Li), liuyu@igsnrr.ac.cn (Y. Liu), xyhou@yic.ac.cn (X. Hou).

${ }^{1}$ Tel: +86 05352109228 .

2 Tel: +861064889471 .

3 Tel: +8615120090948.

${ }^{4}$ Tel: +861064889820.

5 Tel: +8605352109196.
}

context, a large and expanding number of studies have estimated the market and non-market benefits of wetland services. The value of some ecosystem services, such as wetland production, water supply, and shipping, can be directly estimated from their market value. Not all ecosystem services are subject to market transactions. Therefore, surrogate market valuation methods, such as the shadow project method, avoided cost method, carbon tax method, and travel cost method, are required to determine a monetary measure of their value. However, when valuation data are unavailable or lacking for some ecosystem services, such as soil formation and protection, climate regulation, habitat and biodiversity, and cultural service, the conduct of original valuation research on these services are expensive and time consuming. Therefore, benefit transfer provides a cost effective method of extending economic analysis (Brouwer, 2000; Groothuis, 2003).

The middle-lower Yangtze River region, with its lake groups and river systems, is one of the important wetland regions in China. This region suffered the most loss of wetlands during the last 50 years (e.g., 41.0\% loss in Poyang Lake and 34.2\% loss in the JianghanDongting lake group) (CLD, 2005), primarily as an outcome of the reclamation policy by the Chinese government during the staid period (An, 2003). Although research on wetland service valuation has become one of the most significant areas in the last decade or so 
(Zhang et al., 2010), most research results, especially in the middlelower Yangtze River region, are inaccessible to the global research community because they were not reported in English. A limited number of studies about this region have been published in English (Cui et al., 2012; Guo et al., 2000; Jing and Li, 2012; Su and Zhang, 2007; Yang et al., 2008). However, these studies do not necessarily reflect the overall picture of wetland service valuation in the middlelower Yangtze River region, although this region has been characterized as one of the main wetland resource distribution areas in China and one of the world's most ecologically and socio-economically critical ecoregion for biodiversity, freshwater, and terrestrial ecosystems (An et al., 2007).

Thus, physical dimension measurement and monetary evaluation were used to reflect the overall picture of wetland service valuation in the middle-lower Yangtze River region, the results of which would help decision makers avoid inefficiencies in wetland management. Market-based valuation, surrogate market valuation, and benefit transfer methods were used as monetary evaluation methods in this study. To validate the value transfer method, the variation in empirical wetland values in this region was identified by combining the value transfer with Geographic Information System tools (GIS) and then published both in English and Chinese as a case study.

\section{Methods}

\subsection{Study area}

In this paper, the ecosystem services of wetlands in the middlelower Yangtze River region were valuated (Fig. 1). This region, with its lake groups and river systems, is one of the eight important wetland regions in China (An, 2003). As the third longest in the world and the longest and largest river in China, the $6300 \mathrm{~km}$ long Yangtze River flows from west to east and drains into the eastern China Sea in Shanghai. The Yangtze River is divided into several reaches. The middle reach runs between Yichang and Hukou (Poyang Lake mouth), while the lower reach runs between Hukou and Datong. All sections downriver from Datong are considered as estuary. The middle-lower Yangtze River region, with its many bends, is connected with many lakes. This region is referred to as the "Water Realm" is China's major wetland district. The top five largest freshwater lakes in China $\left(10800 \mathrm{~km}^{2}\right.$; dominated by species of Potamogeton, Prgamites, Acorus, Juncus, Ranalisma, Brasenia, Miscanthus, Vallisneria, and Cyperus) are all distributed in the middle-lower Yangtze River region (e.g., Poyang Lake and Dongting Lake), while the tidal wetlands are found near the estuaries of this river. These wetlands provide the most important ecosystem service for the middle-lower Yangtze River region, which has high densities of industry and population. Despite the provision of multiple valuable services, wetlands in this region encounter a number of anthropogenic threats, including destructive and non-sustainable fishing practices, pollution and waste, mining and dredging, and non-sustainable tourism practices.

\subsection{Data description}

The data used to estimate the size of wetland ecosystems were extracted from twelve cloud-free LANDSAT Thematic Mapper (TM)/Enhanced Thematic Mapper (ETM) images obtained in 2009/2010 (data source: http://glovis.usgs.gov/) and DEM data

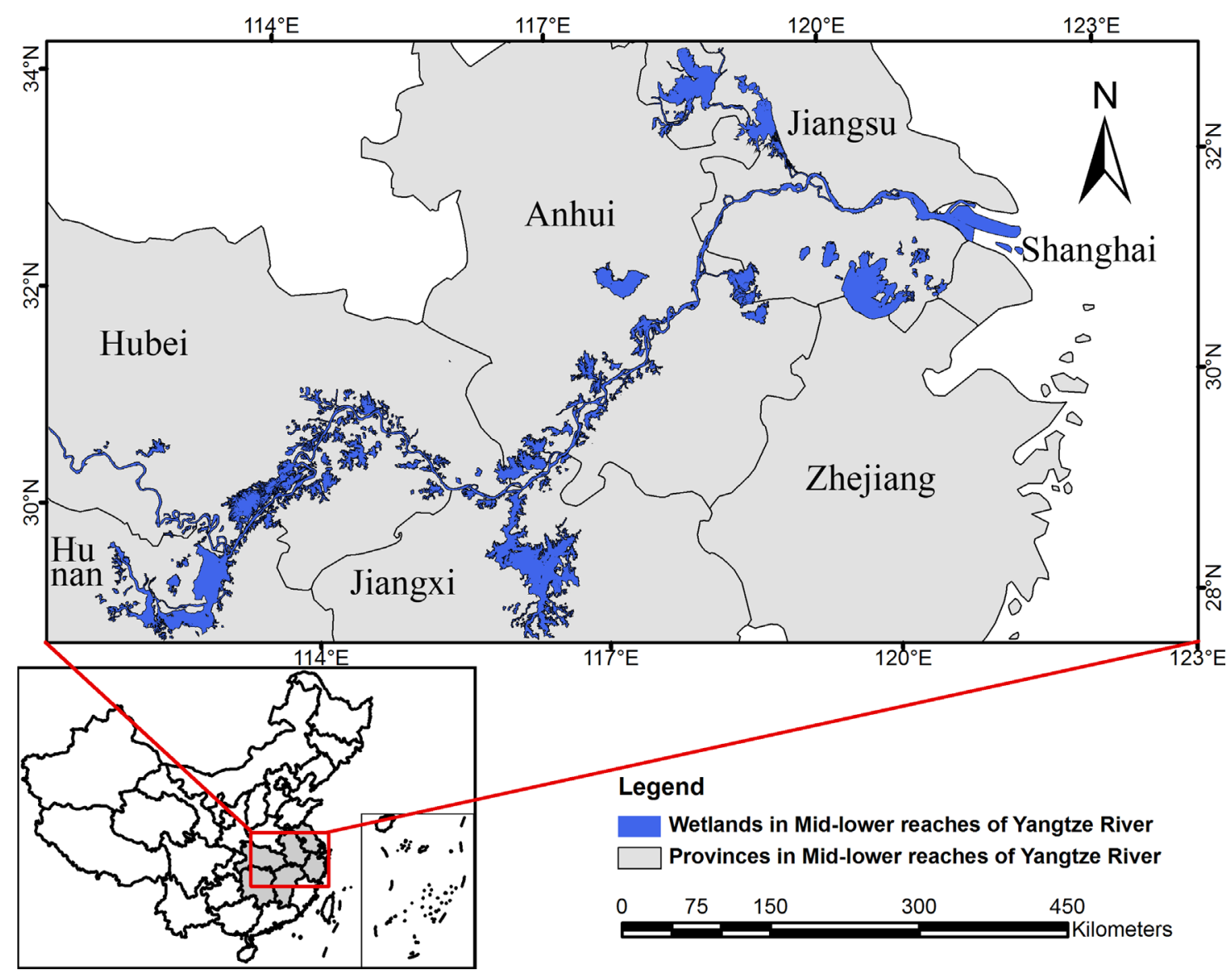

Fig. 1. Location of the study area and distribution of wetlands in the middle-lower Yangtze River region. 
Table 1

method for the two steps.

\begin{tabular}{|c|c|c|c|c|c|c|}
\hline Classification & $\begin{array}{l}\text { Ecosystem services } \\
\text { categories }\end{array}$ & $\begin{array}{l}\text { Physical dimension } \\
\text { estimate index }\end{array}$ & Calculation formulas & Parameter & $\begin{array}{l}\text { Evaluation } \\
\text { method }\end{array}$ & $\begin{array}{l}\text { Value per unit(based on the } 67 \\
\text { literature reviews) }\end{array}$ \\
\hline \multirow[t]{6}{*}{ Provisioning } & \multirow[t]{2}{*}{$\begin{array}{l}\text { wetland } \\
\text { production (plant } \\
\text { and animal) }\end{array}$} & $\begin{array}{l}\text { Annual biomass of } \\
\text { wetland plant }(\mathrm{Wa})\end{array}$ & $\mathrm{Wa}=\mathrm{Si} \times \mathrm{Wi}$ & \multirow{2}{*}{$\begin{array}{l}\text { Si }\left(h^{2}\right) \text { : area of wetland plant; } \\
\text { Wi }(t) \text { : wetland plant harvest per unit } \\
\text { area; } \\
\text { Ai }(t) \text { : fishing amount of species } i \text {; }\end{array}$} & \multirow{2}{*}{$\begin{array}{l}\text { Market } \\
\text { value } \\
\text { method } \\
\text { Market } \\
\text { value } \\
\text { method }\end{array}$} & 107 US \$/t \\
\hline & & $\begin{array}{l}\text { Amount of fishing } \\
(\mathrm{Qr})\end{array}$ & $\mathrm{Qr}=\sum \mathrm{Ai}$ & & & 2443 US $\$ / t$ \\
\hline & \multirow[t]{2}{*}{ Water supply } & \multirow[t]{2}{*}{$\begin{array}{l}\text { Water supply } \\
\text { capacity (Pw) }\end{array}$} & \multirow[t]{2}{*}{$\mathrm{Pw}=\mathrm{Pwc}+\mathrm{Pwv}$} & \multirow[t]{2}{*}{$\begin{array}{l}\text { Pwc }\left(\mathrm{m}^{3}\right) \text { : water supply capacity in } \\
\text { industry and daily life; } \\
\text { Pwv }\left(\mathrm{m}^{3}\right) \text { : water supply capacity in } \\
\text { agriculture; }\end{array}$} & \multirow[t]{2}{*}{$\begin{array}{l}\text { Market } \\
\text { value } \\
\text { method }\end{array}$} & $\begin{array}{l}0.1629 \text { US } \$ / \mathrm{m}^{3} \text { (average price } \\
\text { for water in industry and daily } \\
\text { life); }\end{array}$ \\
\hline & & & & & & $\begin{array}{l}0.0049 \text { US } \$ / \mathrm{m}^{3} \text { (average price } \\
\text { for water in agriculture) }\end{array}$ \\
\hline & \multirow[t]{2}{*}{ Shipping } & \multirow{2}{*}{$\begin{array}{l}\text { Waterway goods } \\
\text { and passenger } \\
\text { transportation }\end{array}$} & \multirow[t]{2}{*}{$\mathrm{Vn}=\mathrm{P} \times \mathrm{Vpv}+\mathrm{G} \times \mathrm{Vgv}$} & Vn ( US \$): Value of shipping; & \multirow{2}{*}{$\begin{array}{l}\text { Market } \\
\text { value } \\
\text { method }\end{array}$} & $\begin{array}{l}0.0391 \text { US \$/passenger } / \mathrm{km} \\
\text { (passenger) }\end{array}$ \\
\hline & & & & $\begin{array}{l}\mathrm{P} \text { (passenger } / \mathrm{km} \text { ): Waterway passenger } \\
\text { transportation; } \\
\text { Vpv (US \$/passenger } / \mathrm{km}) \text { : Average } \\
\text { price for waterway passenger } \\
\text { transportation; } \\
\text { G (t/km): Waterway goods } \\
\text { transportation; } \\
\text { Vgv (US \$/t/km): Average price for } \\
\text { waterway goods transportation; }\end{array}$ & & 0.0098 US \$/t/km (goods) \\
\hline \multirow[t]{5}{*}{ Regulating } & Flood control & Reservoir capacity & $\mathrm{Vt}=1 / \mathrm{n} \sum \operatorname{ciVi}(1+\mathrm{xi})$ & $\begin{array}{l}\text { Vt (US \$): value of flood control; } \\
\text { Vi }\left(\mathrm{m}^{3}\right) \text { : Reservoir capacity; } \\
\text { ci }\left(\text { US } \$ / \mathrm{m}^{3}\right) \text { : Average price for } 1 \mathrm{~m}^{3} \\
\text { Reservoir project; } \\
\text { xi: coefficient of price growth; }\end{array}$ & $\begin{array}{l}\text { Shadow } \\
\text { project } \\
\text { method }\end{array}$ & 0.26 US $\$ / \mathrm{m}^{3}$ \\
\hline & $\begin{array}{l}\text { Water quality } \\
\text { improvement }\end{array}$ & $\begin{array}{l}\text { Removal rates of } \mathrm{N} \\
\text { and } \mathrm{P}\end{array}$ & $\begin{array}{l}\mathrm{Vj}=\mathrm{N} \times \mathrm{Sc} \times \\
\mathrm{b} 1+\mathrm{P} \times \mathrm{Sc} \times \mathrm{b} 2\end{array}$ & $\begin{array}{l}\text { Vj (US \$): value of water quality } \\
\text { improvement; } \\
\mathrm{N}\left(\mathrm{kg} / \mathrm{hm}^{2}\right) \text { : Removal rates of } \mathrm{N} \text {; } \\
\mathrm{P}\left(\mathrm{kg} / \mathrm{hm}^{2}\right) \text { : Removal rates of } \mathrm{P} ; \\
\text { b1 }(\mathrm{US} \$ / \mathrm{kg}) \text { : shadow price for } \mathrm{N} \\
\text { removal; } \\
\text { b2 (US \$/kg): shadow price for } \mathrm{P} \\
\text { removal; } \\
\text { Sc }\left(\mathrm{hm}^{2}\right) \text { : wetland area; }\end{array}$ & $\begin{array}{l}\text { Avoided } \\
\text { cost } \\
\text { method }\end{array}$ & $\begin{array}{l}0.24 \text { US } \$ / k g(N) \\
0.407 \text { US } \$ / k g(P)\end{array}$ \\
\hline & $\begin{array}{l}\text { Soil formation and } \\
\text { protection }\end{array}$ & Area of wetland & $\mathrm{Vr}=\operatorname{Pr} \times \mathrm{Sc}$ & $\begin{array}{l}\text { Vr (US \$): value of soil formation and } \\
\text { erosion control (SFEC); } \\
\text { Pr }\left(\text { US } \$ / \mathrm{hm}^{2}\right) \text { : value per unit area of } \\
\text { SFEC; } \\
\text { Sc }\left(\mathrm{hm}^{2}\right) \text { : wetland area; }\end{array}$ & $\begin{array}{l}\text { Benefit } \\
\text { transfer } \\
\text { method }\end{array}$ & 1469.19 US \$/hm² \\
\hline & Climate regulation & Area of wetland & $\mathrm{Vm}=\mathrm{Pm} \times \mathrm{Sc}$ & $\begin{array}{l}\text { Vm (US \$): value of climate regulation; } \\
\text { Pm (US \$/hm²): value per unit area of } \\
\text { climate regulation; } \\
\text { Sc }\left(\mathrm{hm}^{2}\right) \text { : wetland area; }\end{array}$ & $\begin{array}{l}\text { Benefit } \\
\text { transfer } \\
\text { method }\end{array}$ & 2464 US \$/hm² \\
\hline & Gas regulation & $\begin{array}{l}\text { Carbon fixation } \\
\text { and oxygen release }\end{array}$ & $\begin{array}{l}\mathrm{PCO}_{2}=\mathrm{NPP} \times 1.63 \\
\mathrm{PO}_{2}=\mathrm{NPP} \times 1.20\end{array}$ & $\begin{array}{l}\mathrm{NPP}(\mathrm{t}) \text { : net primary productivity; } \\
\mathrm{PCO}_{2}(\mathrm{t}) \text { : Carbon fixation; } \\
\mathrm{PO}_{2}(\mathrm{t}) \text { : oxygen release; }\end{array}$ & $\begin{array}{l}\text { Carbon tax } \\
\text { method }\end{array}$ & $\begin{array}{l}40.3 \text { US \$/t (Carbon fixation); } \\
65 \text { US \$/t (Oxygen release) }\end{array}$ \\
\hline Supporting & $\begin{array}{l}\text { Habitat and } \\
\text { biodiversity (NHB) }\end{array}$ & $\begin{array}{l}\text { Area of wetland } \\
\text { habitat }\end{array}$ & $\mathrm{Vh}=\mathrm{Ph} \times \mathrm{Mh}$ & $\begin{array}{l}\text { Vh (US \$): value of NHB; } \\
\text { Ph (US \$/hm²/yr): value perunit area } \\
\text { of NHB; } \\
\text { Mh }\left(\mathrm{hm}^{2}\right) \text { : Area of wetland habitat; }\end{array}$ & $\begin{array}{l}\text { Benefit } \\
\text { transfer } \\
\text { method }\end{array}$ & 304 US \$/hm²/yr \\
\hline \multirow[t]{2}{*}{ Cultural } & $\begin{array}{l}\text { Recreation and } \\
\text { tourism }\end{array}$ & Area of wetland & $\begin{array}{l}\mathrm{P}=(\mathrm{P} 1, \ldots, \mathrm{Pn}) \\
\mathrm{Pl}=\sum \mathrm{Pi} \times \mathrm{Ai}\end{array}$ & $\begin{array}{l}\mathrm{Pl}(\mathrm{US} \$) \text { : value of recreation and } \\
\text { tourism; } \\
\mathrm{Ai}\left(\mathrm{hm}^{2}\right) \text { : area of tourism resource } \mathrm{i} \text {; } \\
\mathrm{Pi}\left(\mathrm{US} \$ / \mathrm{hm}^{2}\right) \text { : value per unit area of } \\
\text { tourism resource } \mathrm{i} \text {; }\end{array}$ & $\begin{array}{l}\text { Travel cost } \\
\text { method }\end{array}$ & \\
\hline & Cultural & Area of wetland & $\mathrm{Vc}=\mathrm{Pc} \times \mathrm{Sc}$ & $\begin{array}{l}\text { Vc (US \$): value of cultural; } \\
\text { Pc (US \$/hm²): value per unit area of } \\
\text { cultural; } \\
\text { Sc }\left(\mathrm{hm}^{2}\right) \text { : wetland area; }\end{array}$ & $\begin{array}{l}\text { Benefit } \\
\text { transfer } \\
\text { method }\end{array}$ & 634.1 US $\$ / h^{2}$ \\
\hline
\end{tabular}

ASTER Global Digital Elevation Model (ASTER GDEM) developed by the Ministry of Economy, Trade, and Industry of Japan (METI) and the National Aeronautics and Space Administration (NASA) (data source: http://gdem.ersdac.jspacesystems.or.jp/). Based on the data of the areas of each wetland, the net primary productivity (NPP) of each wetland was collected and calculated. The data used to estimate the 
NPP of wetland ecosystem were extracted from MODIS/Terra Net Primary Production Yearly L4 Global $1 \mathrm{~km}$ SIN Grid V055 (data source: http://reverb.echo.nasa.gov/reverb/datasets).

Wetland valuation studies on the middle-lower Yangtze River region were obtained from online journal databases, libraries, and by personally communicating with authors to conduct the benefit transfer of wetland ecosystem service values (ESV). In total, 67 studies that contained sufficient information for the benefit transfer were identified. Table 2 lists the studies and their corresponding information on the wetland site, area, examined ecosystem type, and number of literature included.

\subsection{Value assessment method}

Although different approaches to ecosystem service classification are available (Turner et al., 2008), the widely accepted framework proposed by the Millennium Ecosystem Assessment (Millennium Ecosystem Assessment, 2005a) was used. This assessment classifies ecosystem services into provisioning, regulating, supporting, and cultural services.

The value of wetland ecosystem services was assessed in two steps: physical dimension measurement and monetary evaluation. The physical dimensions of the wetland ecosystem services were obtained from upscaling with the help of statistical data based on field-scale research in the middle-lower Yangtze River region. The physical dimensions included wetland plant harvest, fishing amount, water supply capacity, waterway passenger/goods transportation, reservoir capacity, and removal rates of N/P, which were obtained from the literature statistical data. Benefit transfer technique was used to obtain necessary coefficient(s) after the large-scale academic literature review to do the upscaling of the result of the field-scale studies. Carbon fixation and oxygen release were calculated based on the NPP data. In contrast to monetary evaluation, physical dimension estimates were more site-specific and data collection was more difficult. Thus, care was necessary when upscaling.

The second step is the monetary evaluation. The value of wetland production, water supply, and shipping were directly estimated from their market value. Surrogate market valuation methods were implemented to estimate the value of flood control, water quality improvement, gas regulation, and recreation service based on the costs of avoided damages emerging from lost ecosystem services, costs of replacing ecosystem services, or costs of providing substitute services. The values of other ecosystem services with limited or absent valuation data, such as soil formation and protection, climate regulation, habitat and biodiversity, and cultural service, were estimated by benefit transfer method. Benefit transfer is an economic valuation tool that obtains valuation estimates from other areas (study sites) and then applies them to a similar location (policy sites) (Brouwer, 2000). This method is conducted by adapting and applying estimates from existing studies that best suit the new context with the application of benefit transfer techniques (Groothuis, 2003). In this paper, benefit transfer was used to obtain necessary coefficient(s) for evaluation after large-scale academic literature review. Given the different characteristics of these wetland ecosystem services, more detailed information on valuation methods is shown in Table 1 . All value estimates were standardized to US\$/ha/yr at 2007 price levels to allow for direct comparison of the study results.

\section{Results}

Based on the combined characteristics of 17 widely accepted wetland ecosystem services, 11 important ecosystem services, namely, wetland production (fisheries and plant stuffs), water supply, shipping, flood control, water quality improvement, soil formation and protection, climate regulation, gas regulation, habitat and biodiversity, recreation and tourism, and cultural services, which are more universal in this region, were selected for the evaluation.

After determining the annual ESV per hectare, a map was created to illustrate the spatial distribution of ecosystem service (Fig. 2). This map shows considerable spatial variability of the wetlands providing ecosystem services. The highest values per hectare were observed in Hong Lake $\left(1.32 \times 10^{5}\right.$ US \$/ha/yr) because of its contributions in flood control and wetland production, followed by Shijiu Lake $\left(7.50 \times 10^{4}\right.$ US $\$ /$ ha/yr $)$ for flood control and wetland production and then Poyang Lake (7.32 $\times 10^{4}$ US $\$ /$ ha/yr) for flood control, wetland production, and water quality improvement. The lowest values were observed in human-made wetlands that are mainly fishponds with low regulating, supporting, and cultural service values.

Table 2

List of studies included in the benefit transfer.

\begin{tabular}{|c|c|c|c|c|}
\hline Province & Wetland site & Area $\left(\mathrm{km}^{2}\right)$ & Literature & Ecosystem type \\
\hline Jiangsu & Tai Lake National Tourism Resort & 160 & 1 & Human-made \\
\hline Jiangsu & Heavy Polluted Area in Tai Lake Basin & 5271.56 & 1 & Lacustrine \\
\hline Jiangsu & Lake Tian-mu catchment, Tai Basin & 8.23 & 1 & Wetland reserve \\
\hline Jiangsu & Tai lake & 36940 & 5 & Lacustrine \\
\hline Shanghai & Qingpu, Dingshan lake & 47.5 & 1 & Human-made \\
\hline Shanghai & Jiading, Shanghai & 2.80 & 1 & Human-made \\
\hline Shanghai & Qingpu, Shanghai & 39.72 & 1 & Human-made \\
\hline Shanghai & Fengxian, Shanghai & 32.19 & 1 & Human-made \\
\hline Shanghai & Dingshan lake & 39.7 & 1 & Human-made \\
\hline Jiangxi & Marsh in Poyang lake, Zhelin, Jiangkou, Hongmen reservoir & 616.66 & 1 & Palustrine \\
\hline Anhui & $\begin{array}{l}\text { Anqing Yangtze Riverine Weyland (Longgan Lake, Huangda Lake, } \\
\text { Bo lake, Wuchang lake, Caizi lake) }\end{array}$ & 1043.52 & 1 & Lacustrine \\
\hline Anhui & Shengjin lake & 333.40 & 1 & Lacustrine \\
\hline Hubei & Natural reserve of Yangtze river dolphin at swan continent & 19 & 1 & Riverine \\
\hline Shanghai & Yangtze river estuary & 2150 & 4 & Marine/Estuarine \\
\hline Anhui & Chao lake Basin & 15595.57 & 4 & Lacustrine \\
\hline Hunan & Dongting lake & 2625 & 19 & Lacustrine \\
\hline Hubei & Baoan lake & 39.3 & 1 & Lacustrine \\
\hline Hubei & Hong lake & 414.12 & 2 & Lacustrine \\
\hline Hubei & Chinese Sturgeon Natural Reserve in Yichang Reach of the Yangtze River & 80 & 1 & Riverine \\
\hline Hubei & Liangzi lake & 379.46 & 2 & Lacustrine \\
\hline Hubei & Zhangdu lake & 185 & 1 & Lacustrine \\
\hline Jiangsu & Hongze lake & 2069 & 7 & Lacustrine \\
\hline Jiangsu & Baoying lake & 42 & 1 & Human-made \\
\hline Jiangxi & Poyang lake & 3950 & 8 & Lacustrine \\
\hline
\end{tabular}




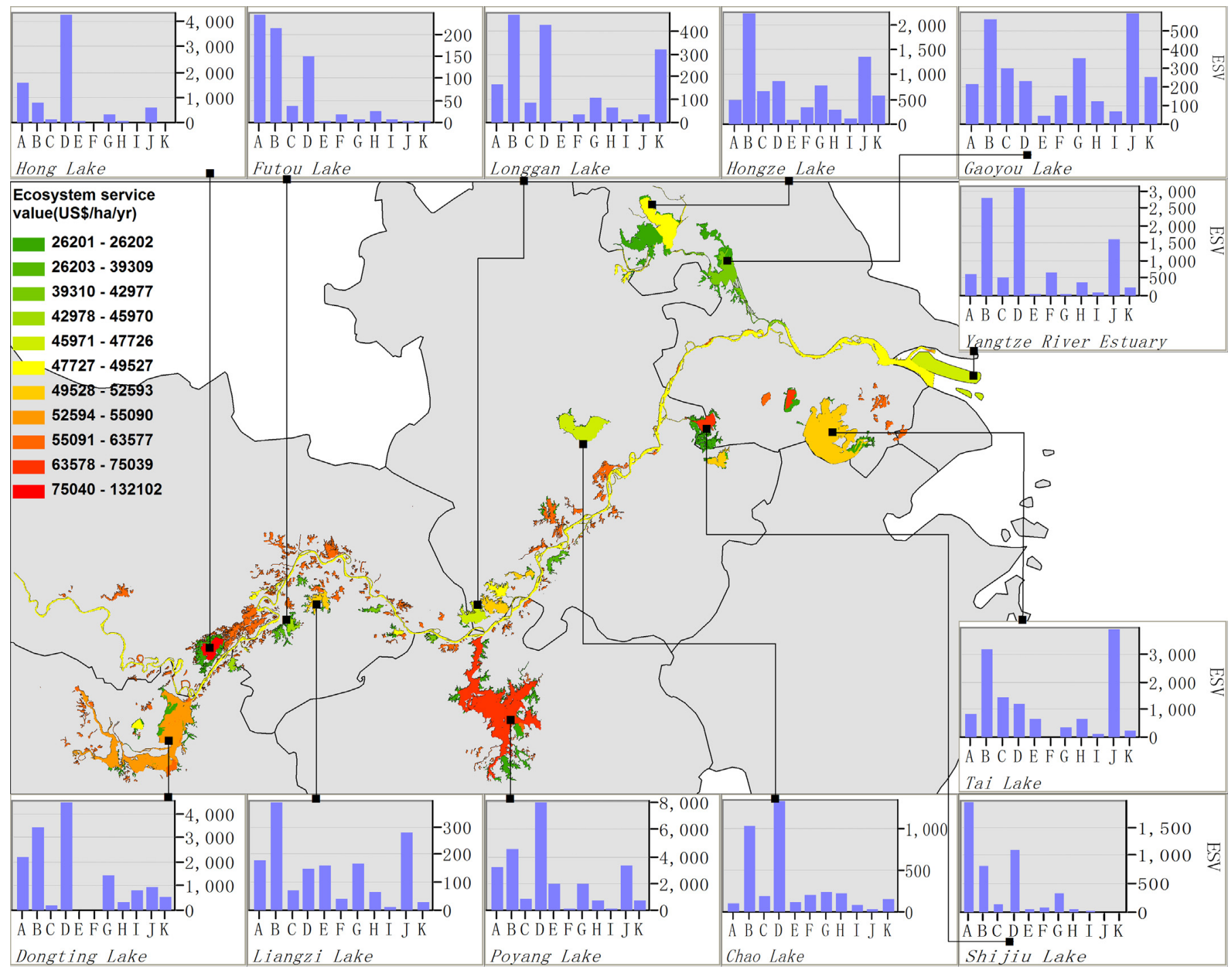

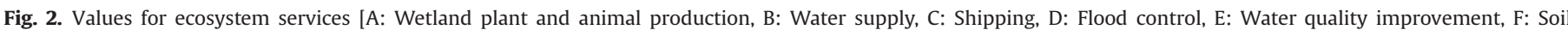

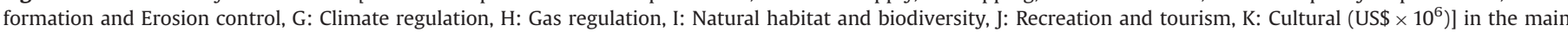
wetlands and annual ESV per hectare in the middle-lower Yangtze River region.

The ESVs of the main wetlands are shown in Fig. 2. Poyang Lake is the region with the highest $\operatorname{ESV}\left(2.57 \times 10^{10}\right.$ US $\left.\$\right)$ because of its valuable services of flood control and water supply, followed by Dongting Lake, Tai Lake, and Yangtze River Estuary because of their contributions of flood control and water supply, except for Tai Lake that has a high value for recreation and tourism service.

The values of natural and human-made wetlands in the middlelower Yangtze River region were compared (Fig. 3). The wetland production value of human-made wetlands $\left(1.99 \times 10^{4} \mathrm{US} \$ / \mathrm{ha} / \mathrm{yr}\right)$ was greater than that of natural wetlands $\left(7.72 \times 10^{3} \mathrm{U} \mathrm{S \$ /ha/yr}\right)$. The values for flood control, recreation and tourism, climate regulation, water supply, cultural service, gas regulation, water quality improvement, and habitat and biodiversity in human-made wetlands were between $71 \%$ and $99 \%$ lower than that in natural wetlands. The calculation results revealed that the value of natural wetlands $\left(5.04 \times 10^{4}\right.$ US $\left.\$ / \mathrm{ha} / \mathrm{yr}\right)$ is greater than that of human-made wetlands $\left(2.62 \times 10^{4} \mathrm{US} \$ / \mathrm{ha} / \mathrm{yr}\right)$. The value for the benefits of human-made wetlands was $48 \%$ lower than that for the benefits of natural wetlands.

The total value of the wetland ecosystem services in the middlelower Yangtze River region was $1.62 \times 10^{11}{\mathrm{US} \$ \mathrm{yr}^{-1}}^{-1}$ (Table 3).

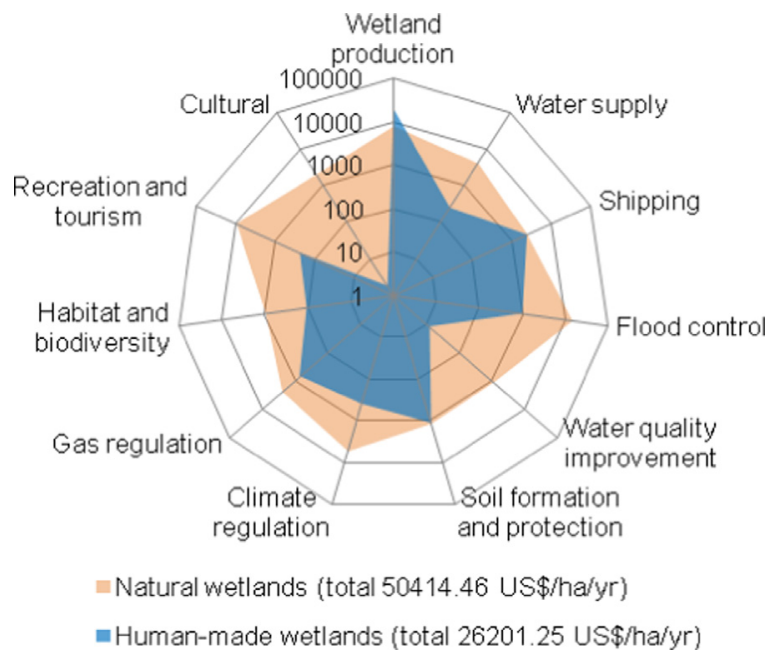

Fig. 3. Values for ecosystem services of natural and human-made wetlands in the middle-lower Yangtze river region. 
Table 3

Value composition estimated by various methodologies for wetland ecosystem services of the middle-lower Yangtze River region.

\begin{tabular}{|c|c|c|c|c|c|}
\hline Classification & Ecosystem services categories & Value (US $\$ \mathrm{yr}^{-1} \times 10^{8}$ ) & Proportion (\%) of total value & Total (US $\$ \mathrm{yr}^{-1} \times 10^{8}$ ) & Proportion (\%) of total value \\
\hline \multirow[t]{3}{*}{ Provisioning } & Wetland production & 176.911 & 10.89 & \multirow[t]{3}{*}{580.349} & \multirow[t]{3}{*}{35.71} \\
\hline & Water supply & 337.894 & 20.79 & & \\
\hline & Shipping & 65.544 & 4.03 & & \\
\hline \multirow[t]{5}{*}{ Regulating } & Flood control & 401.936 & 24.73 & \multirow[t]{5}{*}{638.393} & \multirow[t]{5}{*}{39.28} \\
\hline & Water quality improvement & 45.272 & 2.79 & & \\
\hline & Soil formation and protection & 29.299 & 1.80 & & \\
\hline & Climate regulation & 112.061 & 6.90 & & \\
\hline & Gas regulation & 49.826 & 3.07 & & \\
\hline Supporting & Habitat and biodiversity & 185.482 & 11.41 & 185.482 & 11.41 \\
\hline \multirow[t]{2}{*}{ Cultural } & Recreation and tourism & 170.039 & 10.46 & \multirow[t]{2}{*}{220.827} & \multirow[t]{2}{*}{13.59} \\
\hline & Cultural & 50.789 & 3.13 & & \\
\hline Total value & & 1625.052 & & & \\
\hline
\end{tabular}

In the middle-lower Yangtze River region, the wetland ESVs revealed considerable variability (Table 3 ). Flood control was the

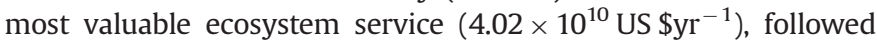
by water supply and habitat biodiversity services $\left(3.38 \times 10^{10}\right.$ and $1.85 \times 10^{10}{\mathrm{US} \$ \mathrm{yr}^{-1}}^{-1}$, respectively). Soil formation and protection was the least valuable ecosystem service $\left(2.93 \times 10^{9}{\text { US } \$ \mathrm{yr}^{-1}}^{-1}\right.$.

The total values by ecosystem service classification also revealed variability. The regulating service provided the highest ESV $\left(6.38 \times 10^{10}{\mathrm{US} \$ \mathrm{yr}^{-1}}^{-1}\right)$ because of the contributions of flood control and climate regulation. Provisioning service also provided high ESV

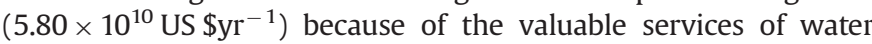
supply and wetland production. The cultural and supporting classes contributed low proportion of the total value (13.6\% and $11.4 \%$, respectively) because these services were valued by benefit transfer method based on the literature data in the middle-lower Yangtze River region. The low value of the cultural and supporting services revealed that further studies are necessary to fully assess the effects of these factors on the cultural and supporting service values in this region.

\section{Discussion}

The assessments in this study would lead people and government officials to realize the importance of wetlands in the middlelower Yangtze River region and identify their core ecosystem services. The value of direct material production, often regarded as the primary service of an ecosystem, has been considered in a number of studies, whereas the values of indirect ecosystem services are usually ignored. In this study, the direct and indirect values of wetland ecosystems had been examined and represented $46.17 \%$ and $53.83 \%$, respectively, of the total values. Recognizing that the value of wetlands in the middle-lower Yangtze River region is mainly embodied as indirect use values, the conservation of regulating and supporting services is argued to be prioritized in the design of future wetland ecosystem management plans.

The value of human-made wetlands obtained in this study was $48 \%$ lower than that of natural wetlands. Other studies also showed the same result, such as the values of converting Thai mangroves to shrimp farms, draining freshwater marshes for intensive agriculture in Canada, and operating unsustainable fishing practices on coral reefs in the Philippines, which were between $60 \%$ and $75 \%$ lower in terms of long-term benefits than those of wetland conservation and sustainable use (Millennium Ecosystem Assessment, 2005b). The result of this paper documents that "conversion of the remaining habitat for agriculture, aquaculture, or forestry often does not make sense based on the perspective of global sustainability"(Balmford et al., 2002). The valuation method of wetland ecosystem services for watershed could be used in other places such as the Mekong river region.

This study is the first to attempt to assess the value of wetlands in the middle-lower Yangtze River region. According to the calculation conducted in this research, the annual total economic value of wetlands in the middle-lower Yangtze River region is US $\$ 162.5$ billion per year, which is higher than the calculation results obtained by Costanza et al. (1997). The value of wetlands in this region was found higher than that of other ecosystem types such as agricultural land (Lv et al., 2010). The total annual value can reflect the high ecological and economic value and irreplaceable importance of wetlands in the middle-lower Yangtze River region. Unfortunately, in the recent years, the in-flow of short-term profits has driven the degradation of wetlands in this region. Signs that wetlands and their ecosystem services in the middle-lower Yangtze River region are decreasing at a higher rate than in other areas in China have been observed (Niu et al., 2011; Wang et al., 2012). Therefore, the government must ensure the formulation and implementation of policies and legislation that will help to address the loss of wetlands in the middle-lower Yangtze River region. The study is supported by the Chinese Academy of Sciences "one three five" strategic planning project of science and technology. Based on the research findings, this study proposes policy recommendations for the middle-lower Yangtze River region wetland conservation (target audience: Wetland Conservation and Management Center of State Forestry Administration, among other central government agencies; as well as the forestry and environmental conservation authorities of wetland provinces/municipalities).

To a limited extent, this paper valued the ecosystem services based on physical dimension measurement and monetary evaluation. Future research may focus on the full assessment of the nonlinear effects of natural/society factors on the ESVs in the middlelower Yangtze River region. The estimation of spatial changes could be significantly improved by analyzing society factors, including road density variables, population, and gross domestic product.

\section{Conclusion}

This study is the first to assess the value of wetlands in the middlelower Yangtze River region. Based on the literature review and remote sensing data, two steps, namely, physical dimension measurement and monetary evaluation, were used in the assessment of 11 wetland service values. The results revealed that the total value of the wetland ecosystem services in the middle-lower Yangtze River region is US $\$ 162.5$ billion per year, which reflects the irreplaceable important role of wetlands in this region. Flood control is the most valuable 
ecosystem service $\left(4.02 \times 10^{10} \mathrm{US}_{\mathrm{yyr}}{ }^{-1}\right)$, followed by water supply

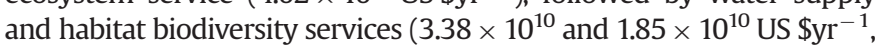
respectively). In the middle-lower Yangtze River region, the wetland ESVs revealed considerable spatial variability. Poyang Lake, Hong Lake, and Shijiu Lake have the highest ESVs. The value of human-made wetlands ( $2.62 \times 10^{4}$ US $\left.\$ / \mathrm{ha} / \mathrm{yr}\right)$ was $48 \%$ lower than that from natural wetlands $\left(5.04 \times 10^{4} \mathrm{US} \$ / \mathrm{ha} / \mathrm{yr}\right)$, which reflects that conversion of natural wetlands for aquaculture does not make sense from the sustainability perspective. Recognizing that the value of wetlands in this region is mainly embodied as indirect use values, conservation of regulating and supporting services should be prioritized in the design of future wetland ecosystem management plans. The assessment results detailed in this paper would lead people and government officials to realize the importance of wetlands in the middle-lower Yangtze River region and identify their core ecosystem services from a socio-economic perspective. Further studies are necessary to fully evaluate the effects of natural/society factors on the ESVs in this region.

\section{Acknowledgments}

The study is supported by the National Natural Science Foundation of China (41171030). We also appreciate the constructive comments and suggestions of the anonymous reviewers.

\section{References}

An, S., 2003. Ecological Engineering of Wetlands. Chemical Industry Press, Beijing. An, S.Q., Li, H.B., Guan, B.H., Zhou, C.F., Wang, Z.S., Deng, Z.F., Zhi, Y.B., Liu, Y.H., Xu, C., Fang, S.B., Jiang, I.H., Li, H.L., 2007. China's natural wetlands: past problems, current status, and future challenges. Ambio 36, 335-342.

Balmford, A., Bruner, A., Cooper, P., Constanza, R., Farber, S., Green, R.E., Jenkins, M., Jefferiss, P., Jessamy, V., Madden, J., Munro, K., Myers, N., Naeem, S., Paavola, J., Rayment, M., Rosendo, S., Roughgarden, J., Trumper, K., Turner, R.K., 2002. Economic reasons for conserving wild nature. Sci. Total Environ., 950-953.
Brouwer, R., 2000. Environmental value transfer: state of the art and future prospects. Ecol. Econ. 32, 137-152.

CLD, 2005. China's Lake Dataset. Regional Data. 〈http://www.lake.csdb.cn/ index-chn.asp $\rangle$.

Costanza, R., d Arge, R., de Groot, R., Farber, S., Grasso, M., Hannon, B., Limburg, K. Naeem, S., O Neill, R.V., Paruelo, J., Raskin, R.G., Sutton, P., van den Belt, M, 1997. The value of the world's ecosystem services and natural capita. Nature 253-260.

Cui, M., Zhou, J.X., Huang, B., 2012. Benefit evaluation of wetlands resource with different modes of protection and utilization in the Dongting Lake region. In Yang, Z., Chen, B. (Eds.), Procedings of the 18th Biennial Isem Conference on Ecological Modelling for Global Change and Coupled Human and Natural System, pp. 2-17.

Groothuis, P.A., 2003. Benefit transfer: a comparison of approaches. Growth Change $36,551-564$

Guo, Z.W., Xiao, X.M., Li, D.M., 2000. An assessment of ecosystem services: water flow regulation and hydroelectric power production. Ecol. Appl. 10, 925-936.

Jing, Z., Li, J., 2012. IEEE, The Evaluation of River Ecosystem Services in Chongming Island, China

Lv, Y., Gu, S.-Z., Guo, D.-m., 2010. Valuing environmental externalities from ricewheat farming in the lower reaches of the Yangtze River. Ecol. Econom. 69, 1436-1442.

Millennium Ecosystem Assessment, 2005. Ecosystem and Human Well-being: Synthesis. Island Press, Washington D.C..

Millennium Ecosystem Assessment, 2005b. Ecosystems and human well-being: wetlands and water synthesis., Washington, DC.

Mitsch, W.J., Gosselink, J.G., 1986. WetlandsVan Nostrand Reinhold, New York.

Niu, Z., Zhang, H., Gong, P., 2011. More protection for China's wetlands. Nature 471 (305-305).

Su, T., Zhang, E., 2007. Ecosystem valuation and the conservation of wild lands in vigorous economic regions: a case study in Jiuduansha Wetland, Shanghai, Chin. Sci. Bull. 52, 2664-2674.

TEEB, 2010. The Economics of Ecosystems and Biodiversity: Ecological and Economic Foundations, London and Washington.

Turner, R.K., Georgiou, S., Fisher, B., 2008. Valuing Ecosystem Services: the Case of Multi-functional Wetlands. Cromwell Press, London.

Wang, Z., Wu, J., Madden, M., Mao, D., 2012. China's wetlands:conservation plans and policy impacts. Ambio 41, 782-786.

Yang, W., Chang, J., Xu, B., Peng, C., Ge, Y., 2008. Ecosystem service value assessment for constructed wetlands: a case study in Hangzhou, China. Ecol. Econom. 68 $116-125$.

Zhang, B., Li, W., Xie, G., 2010. Ecosystem services research in China: progress and perspective. Ecol. Econom. 69, 1389-1395. 